\title{
Accreditation-Based Education Quality of Madrasah Diniyah in the Regional Autonomy Era
}

\author{
Cecep Anwar, Ida Rosyidah, Wawan Setiawan, Ea Cahya Septia Mahen, Ade Aisyah \\ Jurusan Pendidikan Agama Islam \\ UIN Sunan Gunung Djati \\ Bandung, Indonesia \\ cecepanwar@uinsgd.ac.id,iraosyidah@uinsgd.ac.id, wsetiawan@uinsgd.ac.id, ea.cahya@uinsgd.ac.id, adeaisy@uinsgd.ac.id
}

\begin{abstract}
This study describes the curriculum, the state of the teacher, students, infrastructure, learning process and the condition or improvement of the education quality in Madrasah Diniyah Takmiliyah Awaliyah (MDTA) in Sukabumi after accreditation. This study uses a qualitative approach with descriptive analytical methods. Primary data sources are obtained from interviews, observations, and document studies. Data analysis is done by organizing data, describing it into units, synthesizing, to test the validity of the researcher using triangulation techniques. The results achieved from this research are: MDTA education curriculum is divided into two kinds; namely the local curriculum that is still partial and the curriculum of the government which is theoretically sufficient and in accordance with the provisions of the standard curriculum and starts to be used after the first accreditation. The state of the teacher is quite sufficient with diverse academic qualifications and the owned competencies are good enough and support the process of education and learning. Student conditions are in accordance with the rules and characteristics required. In general the quality of MDTA education has increased. When the ideal education quality measure for MDTA is the accreditation score of $A$, then by comparing the accreditation results in 2006, 2009 and 2013 there is an increase, namely by comparing the results of the accreditation, where in 2006 the percentage of MDTA whose accreditation score was A was about $14 \%, 2009$ by $20 \%$ and in 2013 by $37 \%$. The final conclusion is that the process of accreditation and its follow-up efforts can improve the quality of MDTA education.
\end{abstract}

Keywords-accreditation; component; MDTA; regional autonomy

\section{INTRODUCTION}

The Madrasah Diniyah or what is now known as the Madrasah Diniyah Takmiliyah is an Islamic religious education institution that has grown and managed by the community in a very long period of time. In PP No. 55 of 2007 concerning religious matter and religious education explained that, Madrasah Diniyah Takmiliyah education is a non-formal religious education whose existence grows and develops in the community. Although equality education through the Madrasah Diniyah Takmiliyah is intended to provide additional and deepening knowledge of Islam for students of formal or general education at the primary and secondary levels, this institution remains open to anyone who is still in primary and secondary education.
The existence of PP on Religious Matter and Religious Education above where Madrasah Diniyah Takmiliyah (MDT) education is included, indicates that the state acknowledges and makes it an educational institution that is expected to contribute greatly to the realization of national education objectives. In addition to receiving recognition and serious attention from the central government in the form of the National Education and Government Regulations above, on a regional scale particularly at the district and municipal level - religious education, one of which is through Madrasah Diniyah Takmiliyah, from the local government and its DPRD. This is marked by the emergence of many Regional Regulations (PERDA) or Regents / Mayors Regulations that explicitly regulate and place the position of the Madrasah Diniyah Takmiliyah as a separate educational institution with a variety of characteristics.

In the concept and practice of regional autonomy, the (central) government has surrendered many things whose origins become the affairs and authority of the central government. One of them is the problem of education. According to Law no. 32 of 2004 concerning Regional Government Article 1 paragraph (5) states that regional autonomy is the right, authority and obligation of an autonomous region to regulate and manage their own affairs and the interests of the local community in accordance with the laws and regulations. The autonomous region here is intended to be a legal community unit that has regional boundaries that are authorized to regulate and administer the government and the interests of local people according to their own initiative based on the aspirations of the people in the system of the Unitary State of the Republic of Indonesia [1].

Sukabumi Regency is one of the autonomous regions that are very serious in handling education issues, including religious education, one of which is Madrasah Diniyah Takmiliyah, more specifically Madrasah Diniyah Takmiliyah Awaliyah (MDTA). Today, there are many ways that can be done to improve the quality of education, including education at the Madrasah Diniyah Takmiliyah. One of them is through accreditation activities, which is then followed by any treatments or follow-up actions based on the accreditation result.

Initially the concept of accreditation was associated with the effort to provide an assessment of formal education institutions, especially universities. Then it was known that the 
institution was named the National Higher Education Accreditation Board (BAN-PT) and the School / Madrasah Accreditation Agency (BAS / M). It's just that the use of the term accreditation to assess the Diniyah Takmiliyah Madrasah education process is acceptable, as far as the essence is the same, namely measuring and improving the quality of

Conceptually, the definition of accreditation is an assessment process with certain fact-based indicators. Assessors make observations and assessments according to reality, without manipulation [2]. According to Law no. 20 of 2003 concerning National Education System Chapter XVI Article 60, accreditation is carried out to determine the feasibility of education programs and units in formal and nonformal education pathways at all levels and types of education. As one of the autonomous regions that want to improve the quality of education in Madrasah Diniyah Takmiliyah, especially MDTA, the Regional Government of Sukabumi Regency issues a policy in the field of religious education, namely accreditation.

According to Leo Agustino, system theory says that policy making can not be separated from the surrounding environment. Likewise with public policy. Public policy will definitely be formed and shaping the surrounding environment (social, political, economic, and cultural). Where at one time the policy channeled its input into the surrounding environment, but at the same time or another, the surrounding environment limited and forced it on behavior that must be done by decision makers / policy makers. This means that the interaction between the policy environment and the public policy activities themselves have a mutually influence relationship [3].

Formally, the regulation on Madrasah Diniyah accreditation in Sukabumi Regency is contained in Regulation of Sukabumi Regent About Guidance of Madrasah Diniyah Accreditation. The step is very precise and needs to be done considering the number of Madrasah Diniyah Takmiliyah Awaliyah (MDTA) in Sukabumi regency so much, that in 2005 amounted to more than 1000 pieces and continues to increase, while the quality is allegedly still not evenly distributed. Based on initial observations and information received by researchers, most Madrasah Diniyah Takmiliyah Awaliyah in Sukabumi Regency still needs to be improved in quality.

\section{MethodS}

The approach of this research is qualitative approach. The type of data used is the qualitative data in the form of words and actions. The rest are additional data, such as documents and others. This type of data is generated by conducting interviews, observations, participating and document studies. Primary data sources in this study are people who are related to the development of MDTA education quality in Sukabumi Regency. They are the MDTA Head, MDTA teachers, and government officials concerned. In addition there are also data in the form of documents (written) such as reports, in this case for example accreditation and photo reports. Meanwhile the secondary data sources are obtained from books and other documents that are not the main data source, but still support.
Other activities undertaken by researchers in the framework of data collection are to collect, review and analyze documents. The documents referred to are documents about the accreditation process and matters relating to it, namely:

- Manuscript on the field of religious guidance in acceleration "Realization of Changes in Sukabumi Regency Towards Noble, Productive and Prosperous Societies.

- Manuscript of the Sukabumi Regency's Regulation on MDTA accreditation in 2006 and 2014 which form the basis of the implementation of accreditation activities.

- Accreditation Board of Madrasah Diniyah Takmiliyah Sukabumi Regency with various problems

- Recap of the results of MDTA accreditation in 2006, 2009 and 2013 in general and subdistricts.

- Complete results of accreditation for each MDTA in 2009 which describe the conditions and scores of each accreditation component.

- Recap of MDTA Final Exam Results in the last five years.

Data that has been successfully obtained through the various techniques mentioned above and preliminary analysis has been carried out shortly after the withdrawal process in the field, then compiled in format and description (reduction) and presented in a matrix of processing (display) to facilitate analysis (verification).

\section{RESULTS AND DISCUSSION}

\section{A. Implementation of Regional Autonomy in the Context of Improving the Quality of Madrasah Diniyah Takmiliyah Awaliyah (MDTA) Education in Sukabumi Regency}

The quality of MDTA education is one of the things that get important attention from the Sukabumi Regency Government. One of the breakthroughs that have been carried out is the process of accreditation of MDTA which is very large and spread throughout the districts. In this section, the researcher will outline the problem of accreditation which in the researcher's view is a form of implementation of regional autonomy in the context of improving the quality of MDTA education in Sukabumi Regency. The accreditation activities submitted were the first accreditation in 2006. This is because based on the results of this accreditation, the following strategic policies were born in an effort to improve the quality of education in MDTA.

According to several respondents [4-6] interviewed by researchers, in general the background to the implementation of accreditation included: a. The vision and mission of Sukabumi Regency are generally based on noble character (alakhlak al-karimah). It requires concrete efforts by making religion as a reference, b. The establishment of noble character is based on quality of religious education, including those implemented by MDTA, c. The presence of MDTA in Sukabumi Regency is around 2000 with a variety of (suspected) quality levels, where most of them really need to be 
improved in quality, and d. Accreditation is used as a basis for policy making in improving the quality of MDTA education.

MDTA accreditation is operationally carried out by an institution called the Accreditation Board of Madrasah Diniyah Takmiliyah (BAM DT) which was formed and approved by the Decree of the Regent of Sukabumi. The elements involved in it are: a. Local Government, b. Ministry of Religion, especially in this case the Section of Religious Education and Islamic Boarding Schools (Pekapontren), c. Sukabumi Regency Madrasah Diniyah Takmiliyah Communication Forum (FKDT), and d. Assessment Team consisting of MDTA accreditation assessors. Accreditation is carried out in the form of an assessment. Operational implementation is carried out by accreditation assessors with the principles of honesty, independence, professionalism, fairness, openness, excellence in quality, and accountability.

The aspects assessed and the percentage of assessment on MDTA accreditation in 2006 are described in Table 1 as follows:

TABLE I. MDTA ACCREDITATION ASSESSMENT COMPONENTS

\begin{tabular}{|l|l|l|}
\hline No & \multicolumn{1}{|c|}{ Component/ Assessment Aspect } & \multicolumn{1}{|c|}{$\begin{array}{c}\text { Assessment } \\
\text { Percentage }\end{array}$} \\
\hline 1 & Curriculum/ Teaching Learning Process & $14 \%$ \\
\hline 2 & $\begin{array}{l}\text { Administratio/ Madrasah Diniyah } \\
\text { Management }\end{array}$ & $12 \%$ \\
\hline 3 & Organization/ Madrasah Diniyah Institution & $8 \%$ \\
\hline 4 & Infrastructure & $14 \%$ \\
\hline 5 & Employment & $15 \%$ \\
\hline 6 & Financing & $10 \%$ \\
\hline 7 & Students & $10 \%$ \\
\hline 8 & Society Role & $9 \%$ \\
\hline 9 & Environment/Culture & $8 \%$ \\
\hline & Total & $100 \%$ \\
\hline
\end{tabular}

The complete results of accreditation that have been implemented are as follows:

TABLE II. ACCREDITATION RESULT IN 2006

\begin{tabular}{|l|l|l|}
\hline No & \multicolumn{1}{|c|}{ Accreditation Score in 2006 } & \multicolumn{1}{c|}{ A } \\
\hline 1 & A & 273 \\
\hline 2 & B & 587 \\
\hline 3 & $\mathrm{C}$ & 812 \\
\hline 4 & $\mathrm{D} / \mathrm{Tr}$ & 281 \\
\hline \multicolumn{2}{|l|}{ Total MDTA } & 1989 \\
\hline
\end{tabular}

Based on Table 2 above, some of the following can be explained:

- The number of MDTAs that are accredited is very large, although the distribution of the subdistricts is not the same. If it is averaged by the number of sub-districts as many as 47 , the average number of MDTA districts are 42 MDTAs.

- MDTAs that get accreditation score $\mathrm{C}$ are more than those who get the score of B or A. Not to mention there are still many MDTAs get D or not accredited. This shows that most MDTAs in Sukabumi Regency still have to improve their quality / quality. In the absence of any real action or intervention by the government while still involving and empowering the community, most MDTA's conditions will remain apprehensive. Meanwhile, however, every educational institution / unit is required to be able to provide quality education.

Based on the above conditions, there are several actions taken by the Sukabumi Government whose descriptions are explained in the next section, namely: structuring the MDTA curriculum, improving teacher quality, Student Development In academic and non-academic aspects, improving the quality and quantity of educational facilities, improving quality learning process

The curriculum arrangement is intended for the uniformity of the MDTA curriculum, so that all MDTAs have clear direction and guidance in implementing their education and learning process. It is also to facilitate controlling the quality of MDTA in Sukabumi Regency. Teacher quality improvement is intended so that MDTA teachers have better abilities than before accreditation. This is particularly related to the management of the teaching and management of teacher administration. Student coaching is intended for students and graduates of MDTA to have better skills than before accreditation, so in addition to being legally formal they are easily accepted in junior high school / MTs because they have a diploma of MDTA, they are also able to demonstrate great cognitive, affective and psychomotor abilities. Improvement of educational facilities and infrastructure is intended to encourage the smooth and successful process of education and learning in MDTA. Improving the quality of the learning process is intended to support the realization of the Madrasah Diniyah Takmiliyah educational goals and in general the National Education Goals.

\section{B. Sukabumi Regency Education Curriculum}

In general, the Madrasah Diniyah education curriculum in Sukabumi can be divided into two; namely the local curriculum and the curriculum of the government. Local curriculum means a curriculum that is compiled and used by each Madrasah Diniyah, while the curriculum from the government means a curriculum compiled by the government through a team formed by the Sukabumi government. The mention of both is based on time and its use [7-10].

The local curriculum is in the form of a collection of subjects compiled by each Madrasah Diniyah, and given in stages from class I to class VI. The curriculum can be said to be still simple especially if it is associated with the concept of the curriculum in the modern sense as it is now. This is because the local Madrasah Diniyah curriculum is not structured systematically in written documents, but rather a curriculum that is accepted and carried out "for generations in a long time span. The existence of this curriculum makes every MDTA has its own characteristics.

Prior to the curriculum issued by the government in this case the Ministry of Religious Affairs C.Q. Section of Religious Education and Pondok Pesantren, MDTA in Sukabumi Regency uses local curriculum. This is adjusted to each MDTA. In general, the local curriculum used by each 
MDTA has many similarities. The material contained in the local curriculum of MDTA Madrasah Diniyah is prepared by the head of Madrasah and teachers themselves.

Government curriculum is the name of the researcher to distinguish it from the local curriculum of MDTA which has been explained previously. This curriculum was prepared by a team formed by the Government of Sukabumi and submitted by the Regent of Sukabumi. The form is the Sukabumi Regency Regulation No. 30 of 2007 concerning the Curriculum of Madrasah Diniyah Awaliyah in Sukabumi Regency.

The two curricula above have more in common. The difference is more in the details and breadth of the description in certain parts. This can be understood because the Curriculum of Madrasah Diniyah set by the Sukabumi Government through the Regent Regulation was born first, whereas set by the Office of the Ministry of Religious Affairs of West Java Province was born several years after. Even according to some respondents, MDTA Curriculum Sukabumi Regency can be regarded as the forerunner of materials or materials for the birth of the Curriculum Madrasah Diniyah set by the Office of the Ministry of Religious Affairs of West Java Province.

When linked to his theories, the two forms of MDTA education curriculum used in Sukabumi Regency are generally sufficient. Conceptually, the curriculum has met the standard understanding of the curriculum, for example as stated by Saylor, Alexander and Lewis as quoted by Wina Sanjaya which states that the curriculum is a number of subjects that must be taken by students This is in accordance with what was stated by Robert $M$ Hutchins that the curriculum should include grammar, reading, thetoric and logic, and mathematics, and the secondary level introduces the great book of the western world. $[11,12]$.

Based on existing curriculum documents, MDTA education curriculum contains a number of subjects that students must take for six years (grades I - VI) in stages. These subjects are the Koran, Hadith, Aqidah, Akhlak, Fiqh, Islamic dates and Arabic. All of these subjects at the concept level, their objectives and implementation can contribute greatly to the achievement of national and institutional education goals.

The formal philosophy and legal arrangement of MDTA education curriculum is based on the function and purpose of national education which in its document is placed in the introduction. National education functions to develop the ability and form the character and civilization of a dignified nation in order to educate the nation's life. While the goal of national education is the development of the potential of learners to become human beings who believe and piety to God Almighty, have noble character, healthy, knowledgeable, capable, creative, and independent, and become citizens of a democratic and responsible.

The structure of the MDTA curriculum includes the substance of learning taken in one level of education for 6 years from class I to class VI. The curriculum structure is based on the competency standards of Madrasah Diniyah graduates and the competency standard of subject groups with the following conditions:
MDTA curriculum structure based on Sukabumi Regency Head Regulation No. 30 Year 2007 is shown in Table 3 as follows:

TABLE III. STRUCTURE OF MDTA CURRICULUM BASED ON SUKABUMI REGULATION NO. 30 OF 2007

\begin{tabular}{|c|c|c|c|c|c|c|c|}
\hline \multirow[t]{2}{*}{ No. } & \multirow[t]{2}{*}{ Subject Matter } & \multicolumn{6}{|c|}{ Class } \\
\hline & & $I$ & II & III & $I V$ & $\bar{V}$ & $\overline{V I}$ \\
\hline 1 & Al Qur'an & 8 & 6 & 6 & 6 & 6 & 6 \\
\hline 2 & Hadith & 3 & 3 & 3 & 3 & 3 & 3 \\
\hline 3 & Aqidah & 3 & 3 & 3 & 3 & 3 & 3 \\
\hline 4 & Akhlak & 3 & 3 & 3 & 3 & 3 & 3 \\
\hline 5 & Fiqh & 4 & 4 & 4 & 4 & 4 & 4 \\
\hline 6 & Islamic Dates & & 2 & 2 & 2 & 2 & 2 \\
\hline 7 & Arabic & 3 & 3 & 3 & 3 & 3 & 3 \\
\hline & $\begin{array}{|lll|}\begin{array}{l}\text { Total } \\
\text { week }\end{array} & \text { hours per } \\
\end{array}$ & 24 & 24 & 24 & 24 & 24 & 24 \\
\hline
\end{tabular}

The structure of the MDTA curriculum based on the Decree of the Head of the Regional Office of the Ministry of Religion of West Java Province Number: Kw.10.5/I/PP.00.8/4114/2010 is as follows:

TABLE IV. STRUCTURE OF MDTA CURRICULUM BASED ON THE DECISION OF THE HEAD OF THE REGIONAL OFFICE OF THE MINISTRY OF RELIGION, JAVA BARAT PROVINCE

\begin{tabular}{|c|c|c|c|c|c|c|c|}
\hline \multirow{2}{*}{ No } & \multirow{2}{*}{ Subject Matter } & \multicolumn{6}{|c|}{ Number of Learning Hours } \\
\hline & & $I$ & II & III & $I V$ & $V$ & $V I$ \\
\hline 1 & Al Quran & 4 & 4 & 4 & 4 & 4 & 4 \\
\hline 2 & Hadith & 2 & 2 & 2 & 2 & 2 & 2 \\
\hline 3 & Aqidah & 2 & 2 & 2 & 2 & 2 & 2 \\
\hline 4 & Akhlak & 2 & 2 & 2 & 2 & 2 & 2 \\
\hline 5 & Fiqh & 2 & 2 & 2 & 2 & 2 & 2 \\
\hline 6 & Islamic Dates & 2 & 2 & 2 & 2 & 2 & 2 \\
\hline 7 & Arabic & 2 & 2 & 2 & 2 & 2 & 2 \\
\hline 8 & Local Content & 2 & 2 & 2 & 2 & 2 & 2 \\
\hline \multicolumn{2}{|c|}{ Total of Learning Hours } & 18 & 18 & 18 & 18 & 18 & 18 \\
\hline
\end{tabular}

Based on Table 3 and Table 4 above there are some differences, namely as follows:

- The number of hours of the Quran lessons is seen more in the first MDTA curriculum which is 8 hours for class I and 6 hours for class II - VI, while on the second curriculum structure is 4 hours lesson and apply for class I - VI.

- The number of hours of Hadith, Akidah, Akhlak, and Arabic language courses is seen more in the first MDTA curriculum, which is 3 hours for classes I - 6 hours, while in the second curriculum is 2 hours of lessons.

- In the first curriculum structure, Islamic Date subject is given since class II, while in the second curriculum since class I. 
- In the first curriculum structure there are no Local Content subjects, while in the second curriculum there is Local Content.

\section{Teacher of Sukabumi Regency}

Teachers are an important component in the process of education and learning in all educational institutions. This also applies to MDTA in Sukabumi. Its existence is very important and includes factors that influence the quality of education. This is more so when associated with the state of MDTA which, when viewed from the aspect of facilities and infrastructure is still limited. So the existence and role of teachers is crucial for the sustainability of the process of education and learning.

\section{1) Number and Distribution of MDTA Teachers}

Based on data obtained by researchers from the Ministry of Religion Sukabumi Regency Office through the Religious Education Section and Pondok Pesantren, the number of Madrasah Diniyah teachers in 2015 is 8519 people spread over 47 districts. In general, all contribute to the process and results of education. Number and distribution of teachers attached.

\section{2) Academic Qualification of Teachers}

Teacher qualification is one of the things related to the state of the Madrasah Diniyah teacher. Based on the results of the data collection from the Office of the Ministry of Religion of Sukabumi Regency in this case through the Section of Religious Education and Islamic Boarding Schools, in 2010, the data obtained from the Diniyah Madrasah teacher academic qualifications were as follows:

- The number of MDTA teachers who have no formal education is 1138 people

- The number of MDTA teachers whose formal education level is below D IV 5892 people

- The number of MDTA teachers whose formal education level is D IV - S1 is 1431 people

- The number of MDTA teachers whose formal education level is S2 58 people

According to some respondents / informants interviewed by the researchers although many Madrasah Diniyah teachers did not qualify for S1 / D4, this did not mean they did not have the ability to carry out the education and learning process at the Diniyah Madrasah. This is especially for teachers who come from or graduate from Islamic Boarding Schools. Basically the most important demand is the implementation of the education and learning process with the principal indicators of the teacher conveying the subject matter to students. Their knowledge, understanding and mastery of the subject matter are sufficient, even for the subject matter of the Awaliyah level Madrasah Diniyah Takmiliyah level, some of them can be said to be more than adequate.

\section{3) MDTA Teacher Competencies}

Teacher competence is the ability of the teacher and can support the implementation of duties and obligations of teachers in a good and professional. There are six competencies that must be owned by Madrasah Diniyah teachers; namely pedagogic, professional, social, personality, spiritual and leadership competencies. This is based on the four competencies described in Law No. 14 of 2005 concerning Teachers and Lecturers and Decrees of the Minister of Religion (KMA) No. 211 of 2011 concerning Teacher Competence in the Ministry of Religion. The descriptions in this section are not based on the teacher's competence test, but rather based on the results of the research interview with several sources / informants.

\section{MDTA Students}

Like the general concept, MDTA students are children aged 6/7 - 11/12 years studying at MDTA. They are in a period of growth and development that requires guidance and coaching, especially in matters relating to religion and religious activities. According to Zaenal Mutaqin, MDTA students in Sukabumi Regency are the children of the people living around the MDTA. This is consistent with the opinions of several MDTA heads interviewed by researchers. According to some of these respondents, MDTA students are children of community members who need guidance and coaching, especially in religious matters. They need to get guidance and guidance so that the potential of Allah's grace can develop optimally, and later expected to have the skills required in life, especially able to perform the prayers correctly, reading the Koran and having a noble character.

As children who are growing and developing both physically and psychologically, MDTA students gain valuable knowledge and skills in navigating life. With the religious knowledge of their souls they are fortified by divine power so that they avoid doing immoral deeds. They can also carry out sociological roles related to religious life and obligations, such as being muadzdzin, qari / qariah, imam prayer, khatib and so on. In addition, their parents get happiness because they have pious children. Society, nation and state so, because the young generation and their human resources have a noble character.

\section{E. Quality of Education}

The quality of education is one of the important things that must be considered by all parties. All are concerned with quality education. Because education is a system consisting of various components, the improvement of the quality of education is done by improving the quality of its components. Some of them are curricula, teachers, students, infrastructure and learning processes. To see the quality and improvement, there are many ways that can be done. One of them is through accreditation.

As one of the institutions of religious education whose existence is recognized through various formal regulations, the Madrasah Diniyah Takmiliyah, including the MDTA should be upgraded. In this era of regional autonomy, every region seeks to improve the quality of education in general, including religious education in which there is education Madrasah Diniyah Takmiliyah. The Sukabumi Regency Government has carried out an accreditation process to see the state of the MDTA estate in the region. Based on the results of the accreditation, treatment or intervention is carried out in improving its quality. In this section the researcher will explain the state of education quality of MDTA. 
When the first accreditation in 2006 was used as the initial foundation for improving the quality of MDTA education, after the treatment or intervention from the Regional Government, the conditions and improvement of MDTA education quality will be seen based on the results of the last two accreditations namely accreditation in 2009 and 2013 compared to each other including the accreditation results in 2006.

The complete results of the accreditation that has been implemented is shown in Table 5 as follows

TABLE V. RESULT OF MDTA ACCREDITATION IN 2006, 2009, AND 2013

\begin{tabular}{|c|l|c|c|c|c|c|}
\hline No & \multirow{2}{*}{$\begin{array}{c}\text { Year of } \\
\text { Accreditation }\end{array}$} & \multicolumn{4}{|c|}{$\begin{array}{c}\text { Accreditation Score Typology } \\
\text { of MDTA }\end{array}$} & $\begin{array}{c}\text { Total of } \\
\text { MDTA }\end{array}$ \\
\cline { 3 - 7 } & & $\boldsymbol{A}$ & $\boldsymbol{B}$ & $\boldsymbol{C}$ & $\boldsymbol{D}$ & \\
\hline 1 & 2006 & 273 & 587 & 812 & 281 & 1989 \\
\hline 2 & 2009 & 469 & 1174 & 661 & 17 & 2294 \\
\hline 3 & 2013 & 905 & 1121 & 347 & 41 & 2414 \\
\hline
\end{tabular}

Data on the accreditation results above are from MDTA which are spread in 47 Districts in Sukabumi Regency with various MDTAs in each sub-district. If you pay attention to the number of MDTAs that follow accreditation, it always increases. By looking at the MDTA accreditation process, if the best / ideal quality is symbolized by the value of $\mathrm{A}$, then there is a percentage increase from $2006(14 \%)$ to $2009(20 \%)$ by $6 \%$, and from $2009(20 \%)$ to $2013(37 \%)$ amounted to $17 \%$. Based on these results it can be said that the accreditation of MDTA education quality in Sukabumi Regency from 2006 to 2013 has increased.

Based on the results of the analysis of the data that has been collected and see the results of accreditation, the quality of the five components that affect the quality of education in MDTA in Sukabumi, can be explained as follows:

- The quality of the curriculum has undergone a better change. Before accreditation is carried out, the curriculum used in MDTA is partial. This means that it has not been arranged in the same and standard document form. The curriculum used is adjusted to the policies of each MDTA leader or foundation / institution that houses it. After the curriculum accreditation used has been systematically arranged in one form of document that applies to all MDTAs in Sukabumi, although the characteristics of each MDTA are maintained. The curriculum is in conformity with the standard rules and standards of the curriculum used by the education unit. In it there are clear, directed and measurable goals in the form of Competency Standards (SK) and Basic Competencies (KD). Curriculum development is an important thing that is done so as to support the smoothness and success of the learning process. Quality control of education and learning through the standard curriculum and apply thoroughly.

- The quality of MDTA teachers has experienced a better change. Prior to the accreditation there were still many teachers who were not familiar with teacher administration or learning administration. Most of them do not know or are not familiar with syllabus and lesson plans and other instruments. After the accreditation, most MDTA teachers have started to know the teacher administration or the administration of learning, for example, already familiar with the syllabus and RPP, although the implementation is still not optimal. At least when there will be accreditation, the administration of the teacher or the administration of learning is completed. In addition, after the accreditation of the ability of teachers to manage learning has increased. This is possible because of the efforts made by the government or FKDT in providing training to MDTA teachers.

- The quality of MDTA students experiences a better change. Quantitatively the number of school-age children entering MDTA has increased. This is because the parents' attention to the MDTA education has increased, because they expect their children to become sole children with indicators able to perform the prayers correctly, reading the Koran fluently and noble morals. In addition there are demands - even in the form of formal regulations - that one of the formal requirements of children / graduates of SD / MI who will continue their education to junior high school / MTs must attach a diploma of MDTA. In addition, the academic and non academic ability of students has increased. Student interest and talent can be fostered well, for example in the field of sports and Islamic arts. This is because MDTA students are often included in the activities of Sports Week and Art of Madrasah Diniyah (PORSADIN) which are conducted in stages from the sub-district to the national level. Not a few MDTA students who represent the region follow Musabaqah Tilawatil Quran (MTQ) with various branches of the race.

- The quality of educational facilities and infrastructure has increased. This is marked by the more complete learning facilities owned by MDTA, although it is still simple. Most MDTA already have props, for example for learning Tajwid Science, practice of prayer, the management of corpses, and others. The condition of madrasah buildings is mostly permanent, not least the MDTA whose accreditation A has a two-story building with a sufficient number of classes for a number of study groups. Certain Madrasah Diniyah has a library.

- The quality of the learning process has increased. Prior to accreditation, teachers tend to use more conventional methods, with more dominant lectures. The media used is still limited, namely only the blackboard and chalk. After the accreditation of learning, the components are seen to start increasing. Methods, media, learning resources and evaluation of learning have begun to vary in various forms. In general the instructional rules and steps in the learning process have been done well. Improving the quality of the learning process is characterized by better student learning outcomes, so both in quality and quantity has increased. One of them is seen from the Madrasah Final Examination Results. 


\section{CONCLUSION}

Based on the research process that includes the planning, data collection and analysis that has been done, the reality of the five factors that affect the quality of education at MDTA in Sukabumi Regency and the improvement of the quality of education is summarized the quality of education on MDTA in Sukabumi Regency has increased significantly. This can be seen from the accreditation result with the increasing number of MDTA that get the value of A on the last two accreditations that are in $2009(20 \%)$ and $2013(37 \%)$, with the percentage increase of $17 \%$. Based on the above description, the final conclusion can be stated here is the accreditation program can improve the quality of education in Sukabumi Regency.

\section{REFERENCES}

[1] Hasbullah, "Otonomi Pendidikan: Kebijakan Daerah dan Implikasinya Terhadap Penyelenggaraan Pendidikan” Jakarta : Raja Grafindi Persada, 2006.
[2] J.M. Asmani, "Tips Praktis Membangun dan Mengolah Administrasi Sekolah”, Jogjakarta:Diva Press, 2011, p. 184.

[3] L. Agustino, "Dasar-Dasar Kebijakan Publik", Bandung: Alfabeta, 2012, p. 45.

[4] Sukmawijaya (Bupati Sukabumi), 21 Juli 2016, Personal interview.

[5] A. Iskandar (Kepala Bagian Bina Keagamaan Pemerintah Daerah Kabupaten Sukabumi), 23 Juli 2016 Personal interview.

[6] A. Miftah (Ketua Forum Komunikasi Diniyah Takmiliyah (FKDT) Kabupaten Sukabumi), 1 Agustus 2016, Persoonal interview.

[7] Z. Mutaqin (Kepala Seksi Pendidikan Keagamaan dan Pondok Pesantren Kementerian Agama Kantor Kabupaten Sukabumi), 20 Oktober 2016, Personal Interview.

[8] Ijam, ketua Forum Komunikasi Diniyah Takmiliyah (FKDT) Kecamatan Cikembar Kabupaten Sukabumi, 1 Oktober 2016, Personal Interview.

[9] Ilin, Kepala MDTA Sunanul Huda Cikaroya Cisaat Kabupaten Sukabumi, 28 Agustus 2016, Personal Interview.

[10] H. Sugilar (Kepala MDTA Asasul Islamiyah Cikembar), 5 Oktober 2016, Personal Interview.

[11] Z.Z. Abidin, "Sambutan Ketua Umum Majlis Ulama Indonesia Kabupaten Sukabumi", Sukabumi: Pemerintah Kabupaten Sukabumi, t.th, hal. 21.

[12] W. Sanjaya, "Kurikulum dan Pembelajaran”, Jakarta: Kencana Prenada Media, 2010. 